BIBLIOS REVISITED

John C. KOUNTZ: Library Systems Coordinator, California State University and Colleges, Los Angeles. When this article was in preparation, the author was Systems Analyst, Orange County Public Libraries, Orange County, California.

In the following, Orange County Public Library's earlier reports on its BIBLIOS system are updated. Book catalog and circulation control modules are detailed, development and operation costs documented, and a cost comparison for acquisitions cited.

"In 1968 ALA began publishing, through its Information Science and Automation Division, a Journal of Library Automation. It is perhaps appropriate to note that in the first three quarterly issues only one public library project was described (1), and this was a project under contemplation, not one actually in operation." (2) This statement by Dan Melcher to substantiate his contention that library automation is suspect is, in itself, suspect. The public library project alluded to as being contemplated in 1968 was brought to fruition by Orange County (California) Public Library in 1969, and has functioned with startling success ever since. In addition, the finished system was reported to the library (3) and data processing (4) worlds in 1969 and 1970 respectively.

Orange County Public Library's BIBLIOS (Book Inventory Building Library Information Oriented System) is a system designed to fulfill all functional requirements of a multibranch library which is growing by leaps and bounds $(5)$. Specifically these functional requirements are: acquisitions, book processing, catalog maintenance, circulation control, and book fund accounting, in addition to management reporting on a level not practical in a manual system. 


\section{THE FUNCTIONAL SYSTEM}

The interrelation of these system elements is shown diagramatically in Figure 1. Briefly and from a user's point of view, the system works like this:

A title is desired by someone, patron or staff member. The person refers to the book catalog, Figure 2, to see if the item is in the collection. If it is and not in circulation, he gets the book directly. If the item is in circulation, he can submit a request for it-to receive the book on its return. To update the catalog, a cumulative supplement is produced, keeping current the listing of the library's holdings. If the title is not found in the catalog or supplement, the monthly cumulative on-order list, Figure 3 , is consulted. If the title is listed, a request is submitted and, on receipt and processing, the book is released to the requester. If the title is cancelled, the requester is notified.

When a title wanted for the collection is not listed in either the catalog or the cumulative on-order list, a bibliographic information sheet (BIS), Figure 4, is completed and optically scanned into the system. This information is essentially a pre-cataloging bibliographic description of the desired material. Once entered, these same data serve first to create purchase orders and related reports; then, once edited by the catalogers from the book in hand, to create book card and pocket sets (Figure 5), book catalog entries, shown in Figure 2, holding lists (shelf lists) for each branch, and a broad array of operational reports. It is a feature of BIBLIOS that the descriptive data (from the BIS) are entered in their entirety only once. This means that a bibliographic description need not be initialized by each individual using it; rather, it need only be consulted and, if necessary, corrected or deleted. Thus, an entry once in the system is immediately available for, among other purposes, ordering. This is especially significant since it means that each entry in the book catalog, the catalog supplement, the cumulative on-order list, etc., can be ordered against by simply using the key number for the desired item and the number assigned to the branch wishing to order. This poses the possibility of orders for materials which are OP or otherwise not readily available through the usual vendor channels. BIBLIOS addresses these potential errors by listing (pre-vend list, Figure 6) all order requirements for review before they are used to create orders. By editing this list against Books in Print and/or publishers' catalogs and taking corrective action, orders for the unobtainable are short-stopped.

On placing an order, while a unique subpurchase order number is mechanically created, the key number continues to document the title for processing purposes. In this role the key number follows the order until it is filled or cancelled. Thus, the key is used by BIBLIOS to update inventory automatically on receipt of an order and to create the card and pocket sets for those materials received. Finally, the key number is used by the branches to report inventory changes and, as a subset of inventory, for circulation control. 
Since it is through the key number (or key, for short) for a bibliographic citation that the citation is used in the various functions performed by BIBLIOS, perhaps a little detail concerning the key is in order.

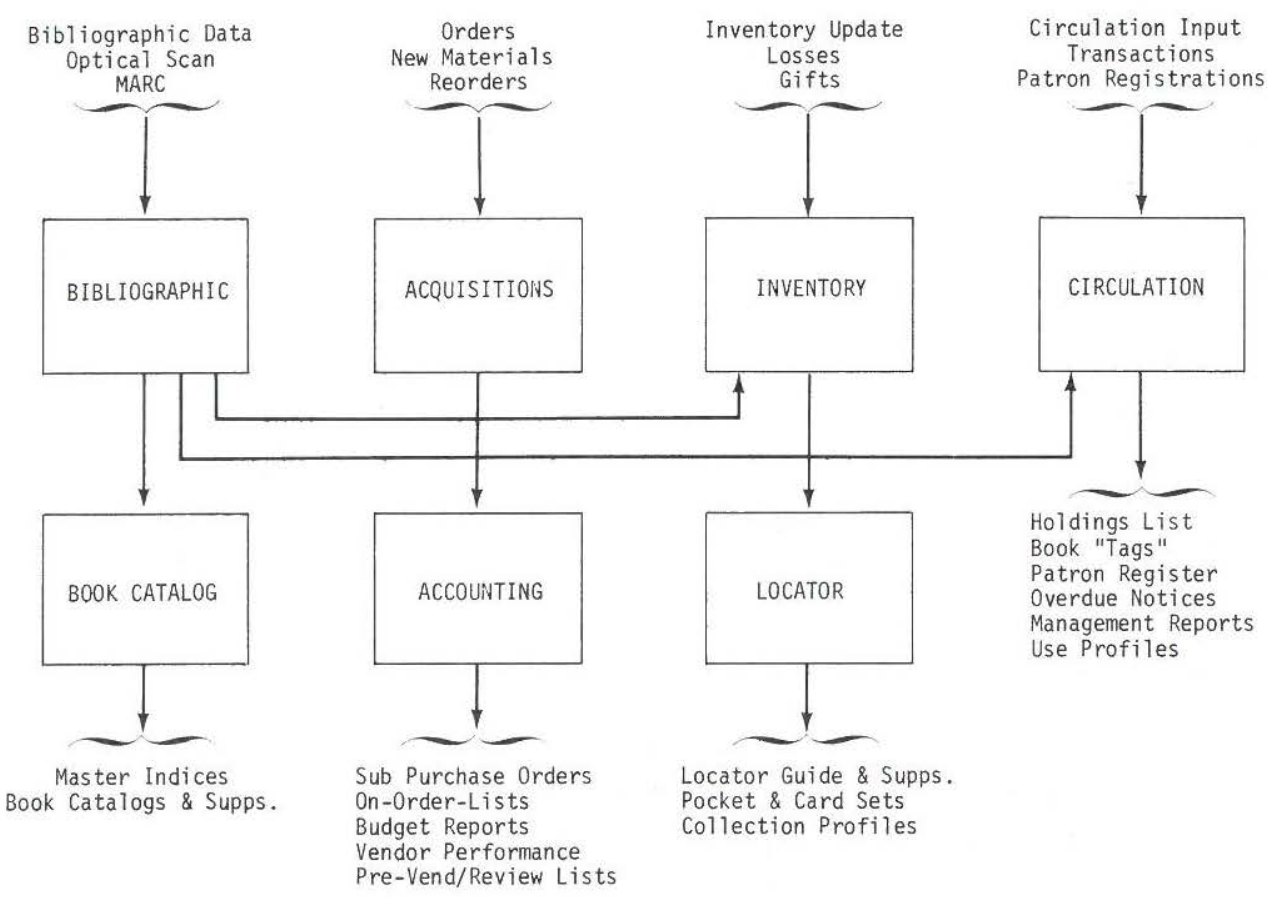

Fig. 1. BIBLIOS-The functional system.

\section{THE KEY NUMBER}

In Figure 2, the key for 73084452 has been underlined. The key number resembles the LC card order number. Wherever an LC card order number is available, it is used. When no LC card order number is available, a unique Orange County (OC) number is applied. The OC number consists of two alphabetic characters in the first two positions (at one time the numbers implied year) of the "traditional" number followed by a six-digit sequential number. Since the Library of Congress has certain idiosyncracies about its card order number, the key also specifies the type of material it represents (for example, only book keys are in the book catalog), and identifies each volume, or edition, of a title which has a blanket LC card order number.

The selection of the LC card order number for this application was based on a suspicion that the bulk of materials in the collection were already 


\section{ADULT CATALOG ' 71 CUMULATIVE SUPPLEMENT 7 AUTHOR-TITLE SECTION}

Wall, Joseph Frazier

Andrew Carnegie. Oxford University. 1970 $92-C$$$
\text { 92-C }
$$

AA006725

Wall, Leonard Vernon Compiler

Extensive Book. Ed of G. A. White. 2nd \& Faber \& Faber. 1965300 p Index Bibliog B/W Illus Photos

$$
791.53
$$

68017740

Wall Street and Witchcraft.

$$
\begin{gathered}
\text { See: Gunther. Max } \\
1331971
\end{gathered}
$$

AA012873

The Wall Street Jungle.

See: Ney, Richard 332.6781970

Wallace, Irving.

76084477

Other Maniacs Simon. Schuster. $1971475 p$ Index Bibliog $B / W$ Illus Biography 301.415

AA011778

Wallace, Marcia.

Barefoot in the Kitchen. A Cookbook for Summer Hostesses. Drawings by Reid Perez Kolman St. Martin's Pr. 1971 150p 641.5

73145431

Wallace, Robert Editor

The World of Bernini. 1598.1680. By Robert Wallace and the Editors of Time-Lite Bibliog Chropodarcel illus
Walter Chandoha's Book of Foals and Horses.

See: Chandoha. Walter

$636.1 \quad 1971$

AA011379

The Walter Syndrome.

See: Neely. Richard

FICTION M 1970

Walters, Barbara.

Practically

808.56

AA007142

Aalues in

Ethos and the Executive values in Managerial Decision Making Prentice-Hall
$1969267 \mathrm{p}$ index Bibliog 658.4

$7 \mathbf{7 3 0 8 4 4 5 2}$

\section{Walton, Izaak.}

The Lives of John Donne and George Herbert John Bunyan the Pilgrim's Progress, by Classics Collier. $1909418 p$

FICTION

09023026-001-015

The Lives of John Donne and George Herbert Bound with the Pigrims Progress. by Classics Collier. 1937418 37040164.001.015

Wambaugh, Joseph. Book Knight. An Atlantic Monthly Press
Bookn. $1972338 \mathrm{p} \mathrm{Lg}$
Ward, Mary Jane.

The Other Caroline. A Novel Crown. 1970 FICTION

70108078

Ward, Ritchie.

he Living Clocks. Drawings by Hollett Smith

$$
\begin{aligned}
& \text { 574.1 } \\
& \text { Illus }
\end{aligned}
$$

77111247

Warde, Frederick B.

Ity Years of Make Believe. By Frederick Warde International $\mathrm{Pr}$ Syndicate 1920 FICTION

21008154

Wardropper, Bruce W. Editor

Spanish Poetry of the Golden Age. Edited by 1971 353p For Lang Poetry Contury Bibliog

78132806

861.08

Publishing

The Clyde Company $1971357 p$ FICTION

AA013079

Warmack, Oliver J.

The Mystery of Iniquity Volume 1.2 Thess.

200 20 Waman G.
Washington, George, Pres. U. S. 1732-1799.

The Journal of Major George Washington. 42 riginal $P$ Reads Wilties. No Printed L London. Reprinted for $I$ Jefferys. 1754. Covers the Period from Oct. 1753 to Jan. 1754 University Microfilms. 1966 $32 \mathrm{p} \mathrm{No}$ Index Maps

973.26 66026314.001

Washington International Arts

Letter Editor

Grants and Aid to Individuals in the Arts Containing Listings of Most Protessional Awards, and intormation About Colleges Arts. by the Editors of the Washington Intl. Arts Letter. Paperback Wash Inti Arts Letter $197075 \mathrm{p}$ No Index

\section{R378.34}

70112695

Waskow, Arthur I.

The Freedom Seder. A New Haggadah for
Passover Holt. Rinehart. Winsto 1970 $56 \mathrm{p} B$ W W Illus

296.437

79103557

Wasley, Ruth.

Bead Design. A Comprehensive Course for Beginner and Experienced Craftsman by 1970216 p Index B.W Illus Col lllus Photos

Fig. 2. A book catalog page featuring four columns. 
assigned a number, a suspicion which was confirmed on completion of conversion through simple reporting of the keys on file. In short, after fifty years of operation of Orange County's libraries, 92 percent of all titles in the collection had an "LC number," a factor one might weigh when trying to decide between ISBN and LC card order number; nor has it been indicated that ISBN's will be developed retrospectively.

\section{AN UPDATE TO THE SYSTEM}

In the paper presented to the American Society for Information Science in 1969 (6), neither the book catalog nor the circulation control modules had been implemented.

\section{Book Catalog}

In May 1971, the first edition of BIBLIOS book catalog was released for public use. Since that date, the cumulative supplement has been run six times. The module of BIBLIOS producing the book catalog and cumulative supplement is diagrammed in Figure 7. Input is the title-master file (the system's bibliographic data base) and a specification of the output required. The output options available to the library include the production of either a full catalog or a cumulative supplement (displaying all entries placed on file since production of the full catalog which have been edited by cataloging). In the case of full catalog production, the title-master file is updated to reflect the use of all qualifying entries for catalog production and the date of their use. This updating facilitates cumulative supplement production by precluding the use of these entries from display until the next full catalog run.

In addition to the type catalog (full or supplement), the library designates the format of the output. Either an off-line print-out or a print file designed to drive a mechanical photocomposition device, or both, can be requested. It is important to note that this print file is designed specifically to be hardware independent, e.g., it will run on RCA, Photon, Alphanumeric, or comparable equipment with equal ease. Hardware independence in its simplest terms means the computer program does not have to be rewritten each time a vendor goes out of business. And, coincidentally, this print file is in the sequence it is to be displayed in. In short, the vendor only performs that processing necessary to make his device set type to the library's specification for layout, font style, and font size-a specification, it might be added, which calls for upper- and lower-case type from a file in upper-case only.

This approach differs from what has become typical of book catalog production in that sorting, file maintenance, and all related processing are sustained by the library through BIBLIOS. The vendor only sets type, prints, and binds. The results spell savings since a potentially error-laden file does not have to be committed to the most expensive of all displays, photocomposition, before corrections can be made. 
LR2OL404 CUMULATIVE ON-OROER LIST

MECIA OI BOUK

AUTHIR

WIDEREERG, SIV

WIDMER, KINGSLEY

WIER, ESTER

WIEST, J, / LEVY, F,

WILCOX, LESLIE A.

WILDER, LAURA (INGALLS)

WILK, MAX

WILKEKSUN, DAVID

WILKES, BILL ST. JOHN

WILKIINSLN, PAUL H.

WILKINSDN, RUPERT

WILLARDS, MILOREO WILDS

WILCOX, DONALD

WJLLECX, DONALD

WILCOX, DONALD

WILLIAMS, BRAO

WILLIAMS, CDLIN

WILLIAMS, ETHEL W.

WILL!AMS, GARTH

WILLIAKS, JAY

Y.ILIIAMS, JOHN G.

WILLIAMS, JOYCE

WILLIAMS, MILLER

WILLIAMS, RDBERT M.

WILLIAMS, TENNESSEE

WILLIAMS, URSULA MORAY

WILLIAMS, URSULA MORAY

WILIAGHAK, WIARREN W.

WILLIS, F, ROY

WILSON, EDMUND

HILSJH, ELLEN JANET (CAME

WILSON, ERICA

WILSIN, H. W.; FIRM, PUBL

WILSON, IRA C.

WYLSON, JEAN

WILSIN, JUHIN RCWAN

WLSUN, KENNETH L.

WINCHELL, CUNSTANCE MABEL.

WINOCHY, EUGENE C.

WINN, MARIE

WINTERIS TALES

WINTERBURN, MOLLIE

WINTERS, DONALD L.

WIRTENGERG, PATRICIA Z.

WISE, ARTHUR

WISE, HERBERT ALVIN

WISE, SIDNEY $T$.

WITHERS, CARL

WITKIN, B. E.
TITLE

MY BEST FRIEND

WAYS OF NIHILISM

WHITE UAK

MANAGEH NT CUIDE TO PERTANSTNIS VUYAGE

BY THE SHERFS OF SILVER L

WIT ANO WISIOM OF HJLLYWU

CROSS AND THE SHITCHBLADE

NAUTICAI ARCHAEULOGY

AIRCRAF ENCINIES DF THE W PREVENTIONS OF ORINKING PR LUCK OF HARRY WEAVER

MUOERN LEATHER DESIGN

NEW UES IGN IN JEWELRY

WOUD DESICH

LOST LEL ENDS CF THE WEST

HOMOSEXEALS AND THE MILIT

KNUH YUUR ANCESTURS

BIG GUL:EN ANIMAL A B C

SILVER PHISTLE

FIELD G.IDE TO THE BUTTER

ADJUSTAELE JULIE

UNLY WD:LD THERE IS

$U C$ L A BUSINESS FORECAST

MILK TRAIN CUESNIT STOP H

BOY IN BARN

THREE TOYMAKERS

FREE-AC E ESS HIGHER EDUCAT

ITALY CLDOSES EUROPE UPSTATE

AHERICAN PAINTER IN PARIS

CREVEL EMBRUIDERY

FICTION CATALJG FOR 1970

WHAT COHIPUTERS CAN NOT DO WEAVING IS FU!

BARR INGTONA

HAVE FA」TH WITHIUT FEAR

GUIDE $T$ REFERENCE BOQKS,

TONKIN ULF

PLAYGRQ: P BOOK

WINTERIS TALES 16, 1970

TECHNIQUE [SF HANDBUILT PU

HENRY C NTMELL WALLACE AS

$A L b-A R B L N D-T H L$ - HWUSE $\triangle R T$

WHIO KILLED ENDCH PURELL

GREAT $T$ LES UF TERRSR / T

INVEST LIND RETIRE IV MEXI

AMERICA. RIDULE BUUK

SUMHARY UF CALIFURNIA LAK

Fig. 3. All outstanding titles are reported in the monthly cumulative onorder list. 


\section{LCMOC. NUMBER}

$7211422 \% \ldots \ldots \ldots$

AAOI1448.......

$73136008 \ldots \ldots \ldots$

$A A O ! 1=53 \ldots \ldots \ldots$.

$73135589 \ldots \ldots \ldots$

$3 \% 027949 \ldots \ldots \ldots$

$73124983 \ldots \ldots \ldots$

$63009442 \ldots \ldots \ldots$

$77159553 \ldots \ldots \ldots$

$41013397 \ldots 0 . \ldots 000.0 .00$

$7306305 \% \ldots \ldots \ldots$

$72131147 \ldots \ldots \ldots$

$69017667 \ldots \ldots \ldots$

$79126870 \ldots \ldots . .$.

$68012400 \ldots \ldots \ldots$

$70080363 \ldots \ldots . .$.

AAO:1209........

$60015252 \ldots \ldots \ldots$

$37004312 \ldots \ldots \ldots$

$71136987 \ldots \ldots \ldots$

$73146: 03 \ldots \ldots \ldots$

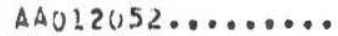

$70122786 \ldots \ldots \ldots$

AAOl7727.......

$03013641 \ldots \ldots \ldots$

$79102411 \ldots \ldots \ldots$

$79152875 \ldots \ldots \ldots$ $4 A 017711 \ldots \ldots \ldots$

$75083024 \ldots \ldots \ldots$

$75143302 \ldots \ldots \ldots$

$70149223 \ldots \ldots \ldots$

$62009837 \ldots \ldots . .$.

$0903504 \% \ldots .0 .070$

$73112925 \ldots \ldots \ldots$

$\triangle A C 13577 \ldots \ldots \ldots$

$72150 \% 26 \ldots \ldots \ldots$

$77124590 \ldots \ldots \ldots$

$\triangle A 006783 \ldots .0067$

$\triangle A C 12355 \ldots \ldots \ldots$

$67013391 \ldots \ldots \ldots$

$55013194 \ldots . .0071$

$4 A 017794 \ldots \ldots . .$.

$766,30195 \ldots . . . .$.

$63028053 \ldots \ldots \ldots$

$76148431 \ldots \ldots \ldots$

$48005552 \ldots \ldots \ldots$

AAO17085...........

$53010334 \ldots \ldots \ldots$

$60004794 \ldots . .169$
SUB PU NBR.

LB ORDER ND

7127707747

7117908249

7127705427

7113002033

7127700303

7117918530

$7122105 \div 61$

7125600790

7127703436

7122105480

$71097040 \% 0$

7122107263

7125602394

7122103587

7127705530

7127702979

7125605046

7127702742

71221000631

7122104431

7). 25601168

7122100095

7125602623

7116109875

7125605433

7127700037

7127724668

7110108405

7127702651

7125603013

7125600143

7127701161

7125609780

71221120 ดั

7127708084

$7125607 i 64$

7125605013

$7117903+15$

7!25308130

7127711323

7127700831

7110104069

7127707032

7122100197

7125603651

7127702071

$7117918: 94$

7127705905

7222109007
VENOOR

QTY CD

ET

BRD

$B R E I$

ERO

QRO

PKW

BRD

BRO

BRD

$\mathrm{CH}$

BRD

BT

BरC.

BRO

GRD

BRD

$B T$

ถรก

BKD

BRD

BKU

EFI

ERD

$\mathrm{CH}$

BT

BPC

SKO

$\mathrm{CH}$

\&RL

BKC

Bर?

हरण

HI

PKiW

BT

DD

BT

BRD

OD

CMA

B?

BRD

E.

[:R]

Bर०

BRO

UKN

BT

C.H
LIST

PRICE

3.80

$7.0 n$

3.35

4.95

8.95

2.80

7.95

4.95

7.93

25.00

10.500

4.50

12.50

7.50

8.95

3.95

8.93

5.00

3.30

3.47

3.82

1.35

4.95

10.00

3.75

3. 8 ก

3. 80

6.30

8.50

$8.9 \div$

4.95

7.50

25.00

0.95

5.95

5.95

3.95

4.00

6.95

4.95

5.95

10.00

8.95

5.00

3.95

$4.9 \%$

1.95

3.50

25.00 


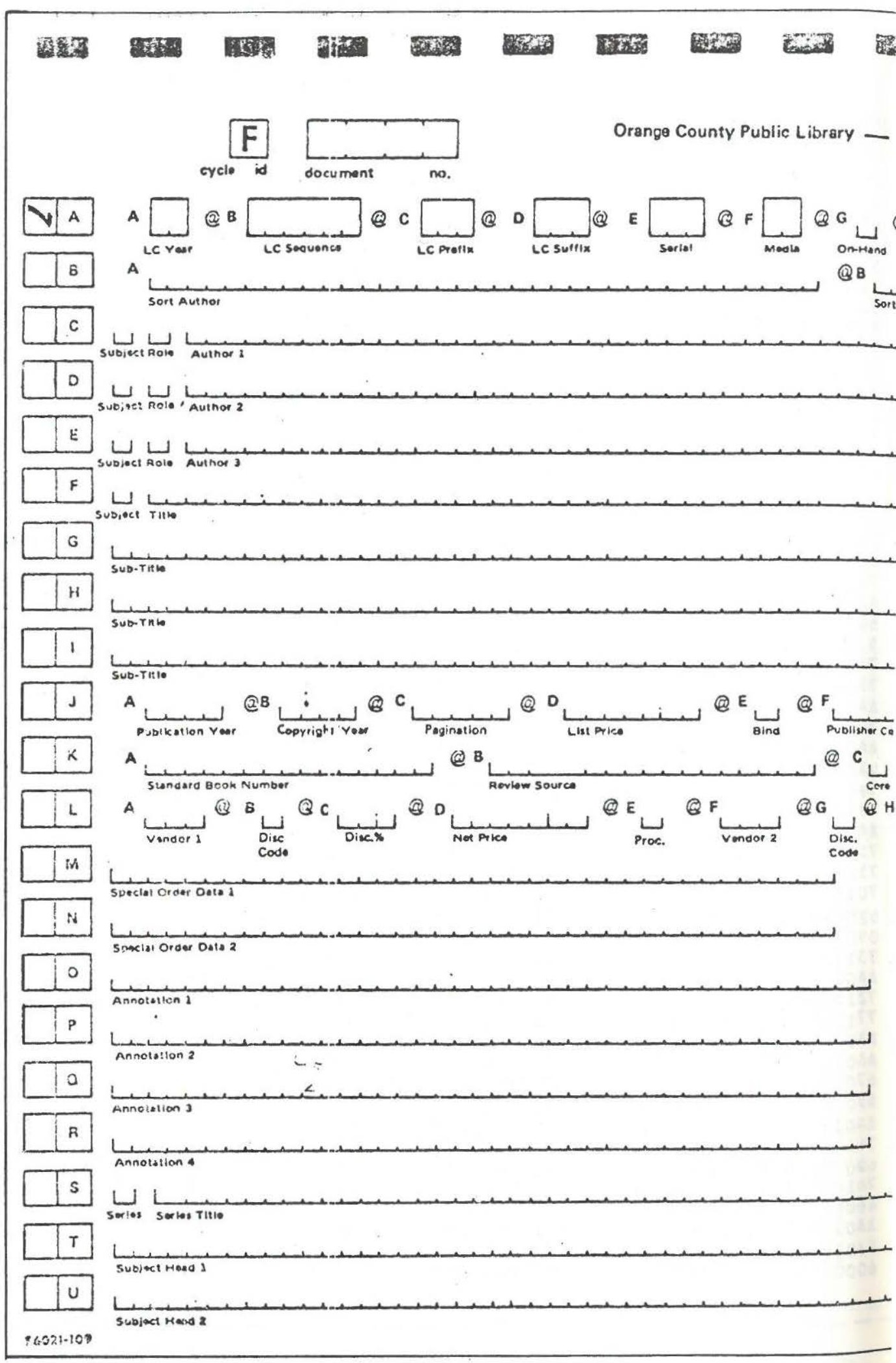

Fig. 4. It all begins with the bibliographic information sheet (BIS). 


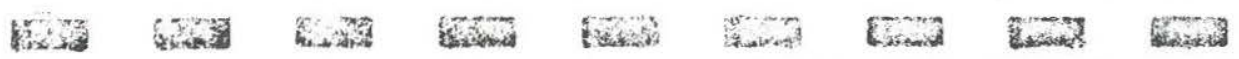

bliographic Information Sheet

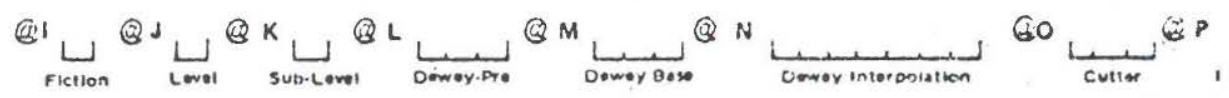
$1 Q$

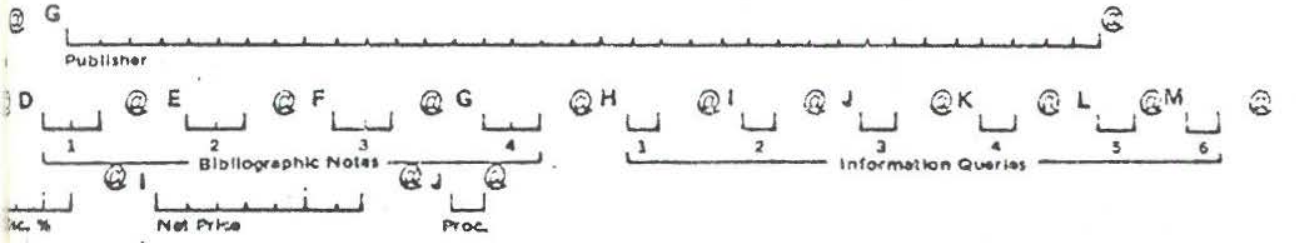




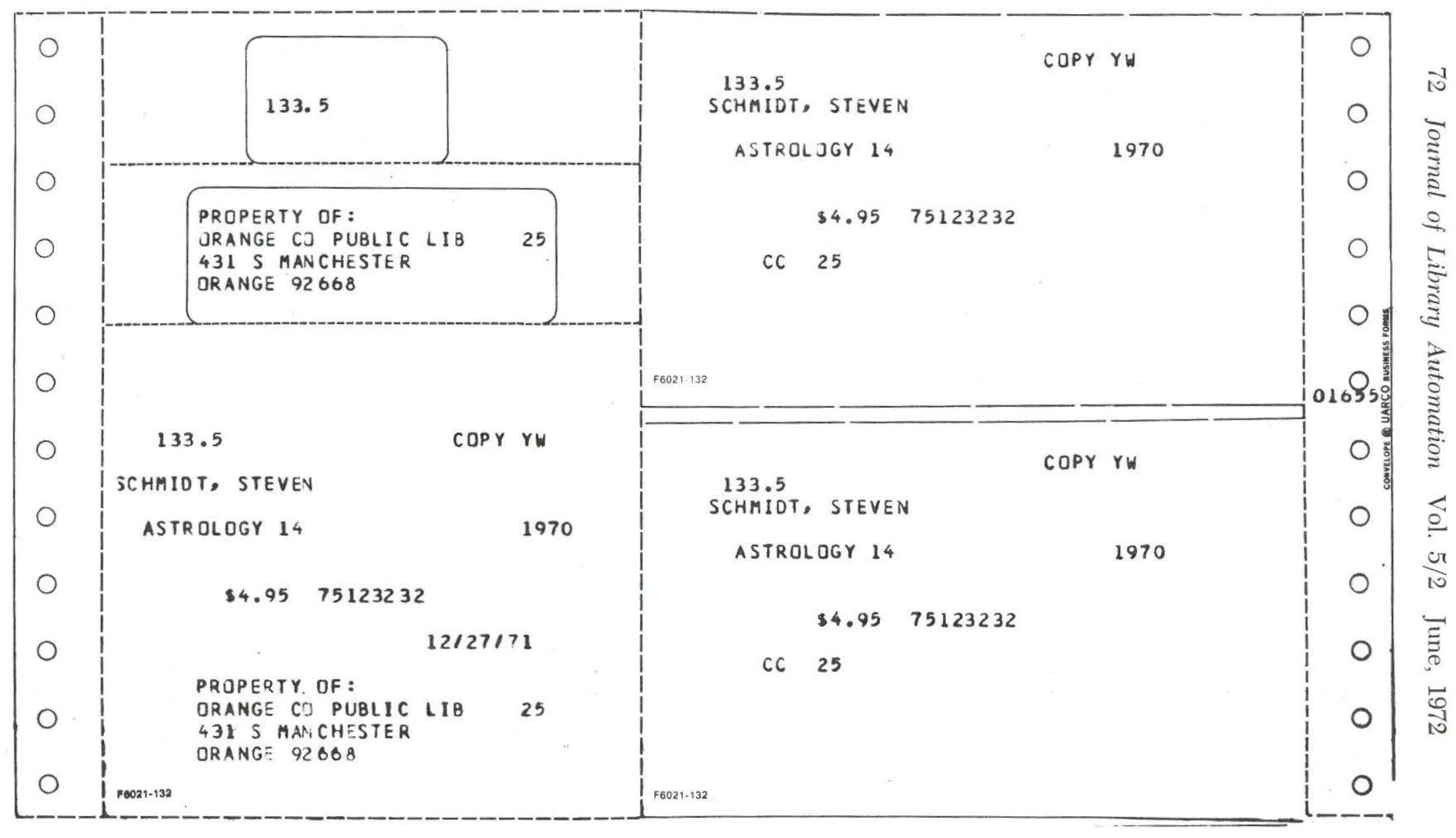

Fig. 5. Pocket, circulation cards, spine label, and property stamp are machine-generated for each addition to inventory (reduced by 20 percent). 
Holdings data are not included in the Book Catalog. Holdings are displayed separately in the locator guide (Figure 8), where the key for each item in the book catalog which has inventory is listed in concert with the numbers for these branches holding the item and, when more than one copy is held, the number of copies. The locator guide is kept current with a cumulative supplement which lists all changes to inventory. This approach, rather than displaying holdings in the book catalog, was chosen for a variety of reasons. First, it makes little sense to display strictly numeric data which lend themselves to tightly packed typography in a format designed for text and for which a premium page rate is being paid. Second, inventory data are volatile for a multibranch library. The holdings of any given branch vary significantly from month to month due to patron losses, acquisitions, gifts, etc. In addition, holdings (inventory) shifts are fostered by a standing policy that titles not being used extensively at one branch be reassigned to another branch to fill a known requirement.

While the locator guide tracks the holdings for all titles in the collection, BIBLIOS also creates holdings lists (Figure 9) for each branch. These lists display, in shelf-list sequence, the materials in each branch's collection. In use, they replace the traditional shelf list (and related filing) at the individual branch as well as facilitating periodic full branch inventory to maintain the accuracy of the inventory master file. Reporting, for inventory purposes, uses the key number for the affected items.

\section{Circulation Control}

Where the book catalog and allied subsystem components have been successfully implemented, circulation control (for lack of a device to economically capture circulation transaction data) has not. An economical data collection unit designed for libraries has not been developed to date by any major manufacturer. In those cases where a machine having the necessary characteristics is offered, it invariably is the product of an undercapitalized firm which promptly goes broke after demonstrating its prototype. The result of this "state of the hardware art" is that the ten fully coded and tested programs in the BIBLIOS circulation control subsystem have been shelved.

Operational, though not operating, this subsystem which is shown diagramatically in Figure 10, draws on the two major data bases maintained by BIBLIOS, the Title-Master and Inventory Master Files. For implementation, the manual registration files now resident in the branches would have to be converted, and book tags or cards would have to be generated and placed with their respective volumes. When these requirements are satisfied, the only remaining input would be circulation transactions created from "marked book" (7), patron card, and the yet-to-bemarketed transactor. These data elements would be patron number, key number, branch number, and Julian date. The method used to capture this transaction input could take any of a broad array of formats (punched 


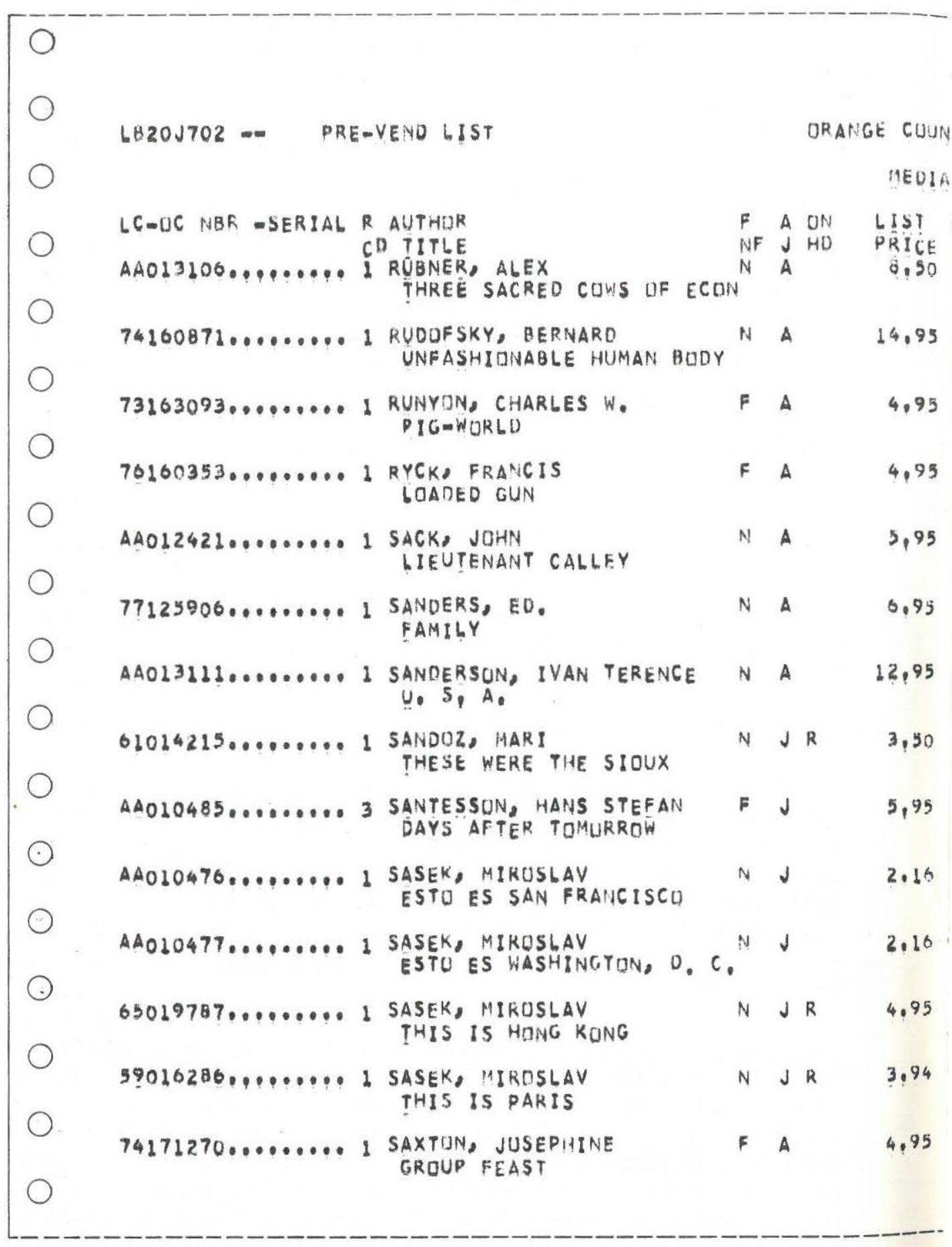

Fig. 6. Before producing a sub-P.O., the pre-vend list is checked for O.P. materials, among other things. 
01 Bugk

TY PUBLISHEF SPECIAL DRDER UATA

3 RARNES-NUALE ...ECIINOHICS

5 DOUBLEDAY SF

9 STEIH-DAY

2 VIKING PRESS

3 E. P. DUTTON

2 RANO MCNALLY

1 HASTINGS HQUSE
4 DOUBLEDAY

UATE

1971

1971

1971

1971

$19 ? 1$

1971

1971

1961

13 LITTLE, BRQWN JLG DISTRIBUTFU BY DUUBLEOAY?

9 MULINO) PRIYYECTO-LEER URDEK UEPT, BRUSDART

10 MILLNOJ

PROYECTM-LEER URUEK UEPT, 'BRO-DART

1 MACMILLANGNY

1 MACMILLAINONY

G DOJUALEDAY
1905

1959

1971
VUR D DISC NEI PR AY CD CDPCT PRIECE CD CD TBRO A BT $A$

由O A

\#D $A$

- Bisu a

B? A

$B$ BT A
BRD A

WBT A

BRO A

*BRO A

BT $A$

BT $A$

CBRि A

* BT C

A

$c$

$\% \mathrm{CH} \quad \mathrm{C}$

$\because \mathrm{CH} \quad \mathrm{C}$

*DD A 
76 Journal of Library Automation Vol. 5/2 June, 1972

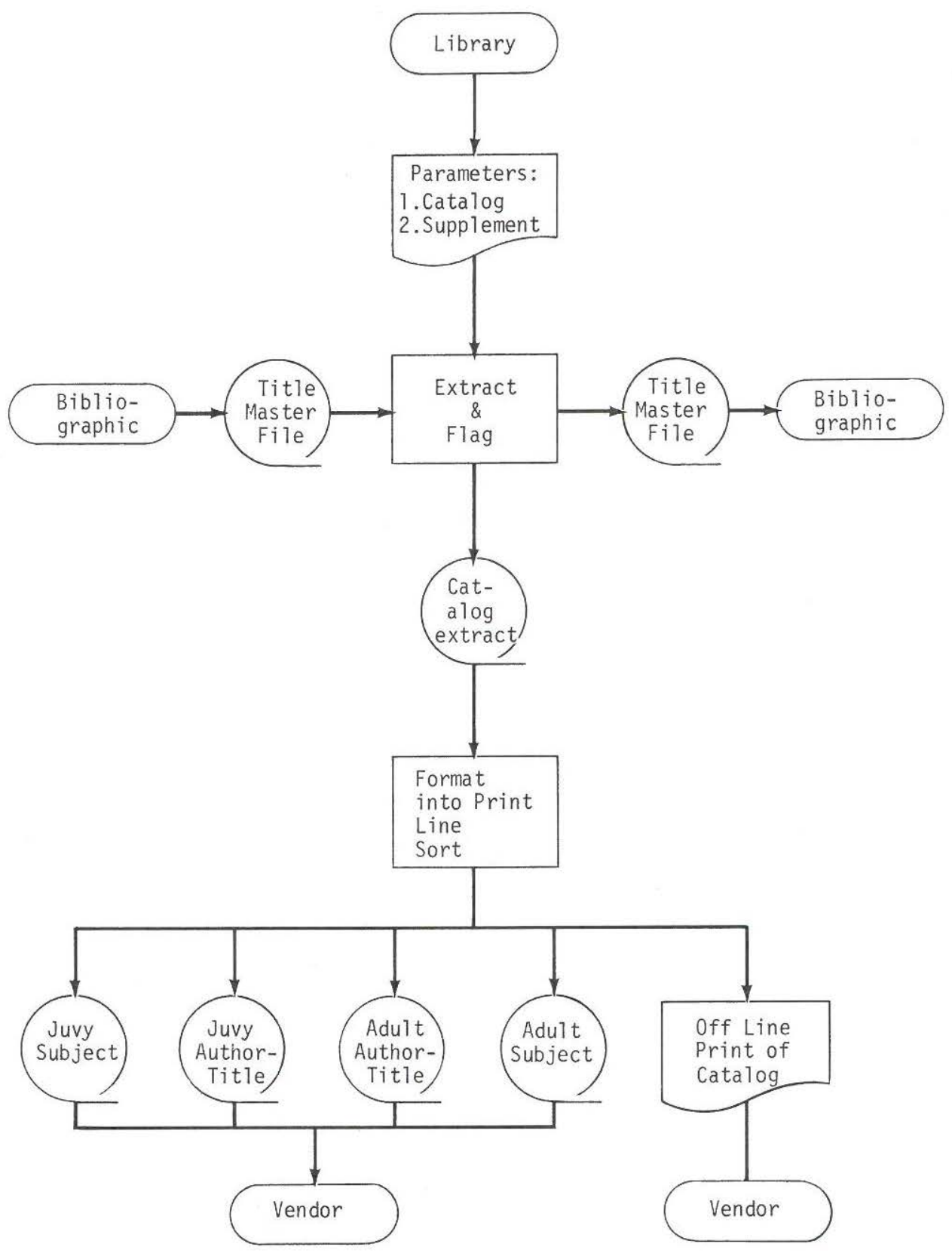

Fig. 7. BIBLIOS book catalog subsystem. 


\section{$140 \quad 52012816-52014177$}

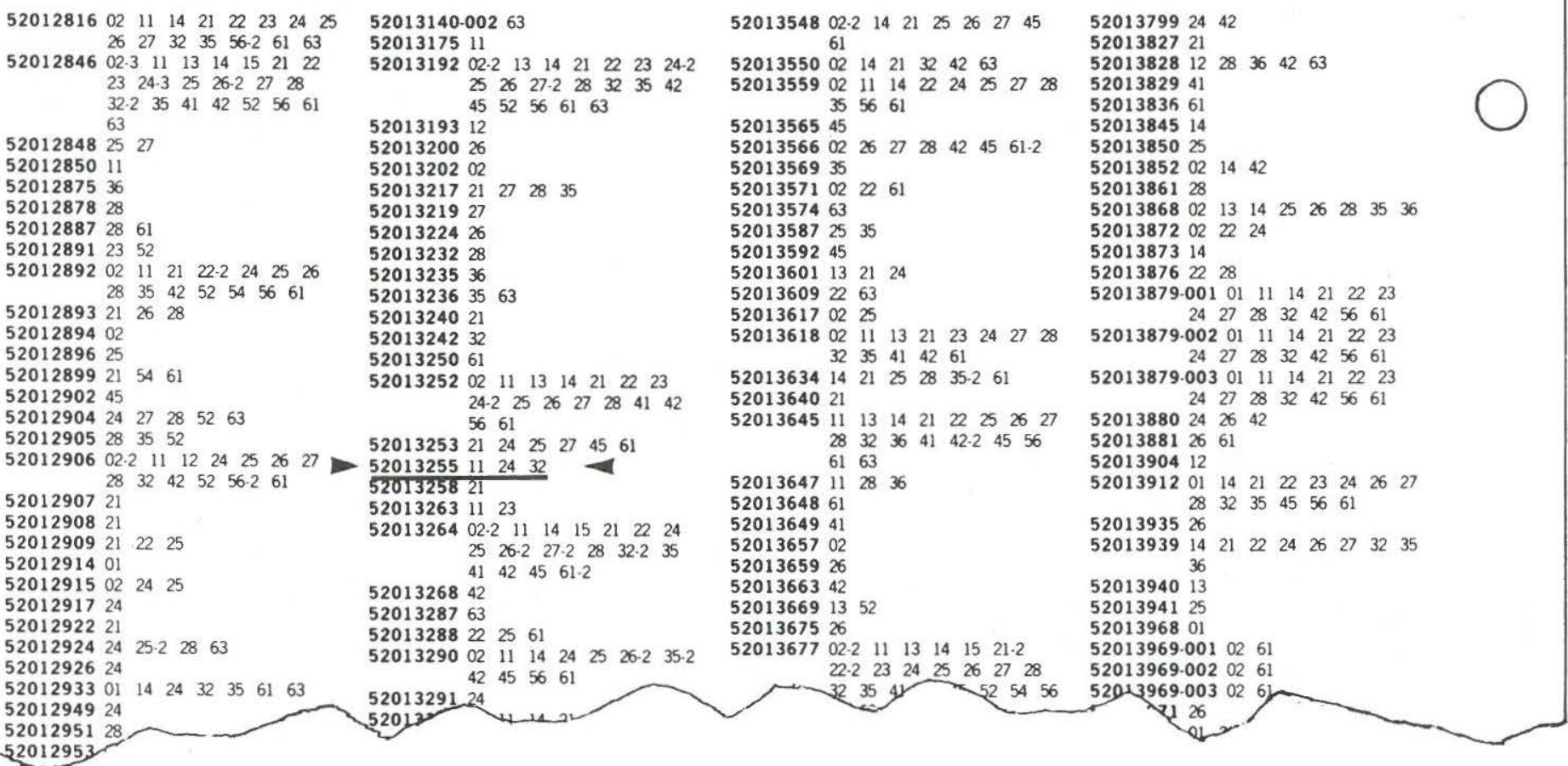

Fig. 8. If a title listed in the book catalog has inventory, the key, branch number, and copy count are displayed in the locator guide. 
795.415

795.415

795.415

795.415

795.41503

795.42

795.42

795.438

795.438

795.540973

796

796

796

796

796

796

796

796

796.026

796.03

796.068

796.068

796.069

796.08

796.08

796.082

796.082

796.09

796.0973

796.0973

796.0973

796.0973

796.0973

796.1

796.13

796.15

796.3

796.31

796.31

196.323

796.323

796.32307

796.323092

796.323092

796.3236

796.33

796.332

796.33203

796.332058

796.33206

796.332077

796.332077

796.332082

796.33209
REESE TERENCE * STORY OF AN ACCUSATION

SHEINWOLD ALFRED * SHORT CUT TO WINNING BRIDGE SNITH THOMAS M $\%$ LOOK IT UP IN MOYLE

YCUNG RAY BRIDGE FOR PEOPLE WHO OON T KNOH OH REESE TERENCE * BRIDGE PLAYER S DICTIONARY

CCLLVER DONALD I \$ SCIENTIFIC BLACKJACK ANO COH THQRP EOWARO O BEAT THE DEALER A WINNING STR BLACKSTONE HARRY * BLACKSTONE S MODERN CARD TR STANYON ELLIS * CARD TRICKS FOR EVERYONE RAND MCNALLY * 1970 RAND MCNALLY GUIDEBOCK TO BISHER FUR MAN * WITH A SOUTHERN EXPOSURE KROUT JOHN ALLEN * ANNALS OF AMERICAN SPORT MITTELBUSCHER C F * CALL EM RIGHT MURRAY JIM * SPORTING WORLO OF JIM MURRAY SMITH ROBERT MILLER * GRANTLAND RICE AHARD PRI SMITH WALTER WELLESLEY * VIEWS CF SPORT VANNIER MARYHELEN * INOIVIOUAL ANO TEAM SPORTS WOOD CLEMENT * COMPLETE BOOK OF GAMES

SPORTS RULES ENCYCLOPEDIA * SPORTS RULES ENCYCL SALAK JOHN S OICTIONARY OF AMERICAN SPORTS AARON DAVIO * CHILO S PLAY BUTLER GEORGE D * RECREATION AREAS

ISAACS STAN * CAREERS AND OPPORTUNITIES IN SPOR PEPE PHILIP $S$ WINNERS NEVER QUIT

WIND HERBERT WARREN * REALM OF SPORT

ESQUIRE * ESQUIRE S GREAT MEN AND MOMENTS IN SP SPORTS ILLUSTRATEO — SPORTS THE AMERICAN SCENE COHANE TIMOTHY BYPATHS OF GLORY

BEST SPORTS STORIES * BEST SPQRTS STORIES FOR BEST SPORTS STQRIES * BEST SPORTS STORIES FOR BEST SPORTS STORIES BEST SPORTS STORIES FQR BEST SPORTS STORIES * BEST SPORTS STORIES FOR BEST SPORTS STORIES * BEST SPORTS STORIES FOR BROER MARI ON R FUNDAMENTALS OF MARCHING

CHASE RICHARD * HULLABALOO AND OTHER SINGING FE WAGENVOORO JAMES FLYING KITES

HOLT RICHARO TEACH YOURSELF BILLIAROS ANO SNE AMATEUR ATHLETIC UNION * OFFICIAL RULES HANDBAI MAXWELL HARVEY C AMERICAN LAWN BOWLER S GUID? AMATEUR ATHLETIC UNION OFFICIAL A A U BASKETI SPORTS ILLUSTRATEO * BOOK OF BASKETBALL

VEROERAME SAL REO * CRGANIZATION FOR CHAMPIONSH AUERBACH ARNOLO RED REO AUERBACH WINNING THE PETTIT BOB * BOB PETTIT THE ORIVE WITHIN ME AXTHELM PETE * CITY GAME

CCNERLY CHARLIE * FORHARD PASS

SCHENKEL CHRIS * HOW TO WATCH FOOTBALL ON TELEI TREAT ROGER L * ENCYCLOPEDIA OF FOOTBALL RIGER ROBERT * BEST PLAYS OF THE YEAR 1962 CURRAN BOB FOUR HUNDRED THOUSAND DOLLAR QUAR DEVINE DAN MISSOURI POHER FODTBALL

SCMOQR GENE * TREASURY OF NOTRE DAME FOOTBALL NEWCOMBE AACK * FIRESIDE BOOK DF FOOTBALL BELL JOSEPH N * BOHL GAME THRILLS

Fig. 9. The maintenance of manual shelfists is obviated by a BIBLIOSproduced holdings list for each branch. 
ION-FICTION

ITLE

R S NBR LCIOC NBR

\section{: CARO FROM ANOTHER}

DLETE CASINO gUIDE

TEGY FOR THE GAME OF TWENTY ONE :KS

IMPGROUNDS REV EO

\section{SPORTS STORIES}

:OR GIRLS ANO WOMEN

DPEOIA

is

ORTS

961

963

964

966

970

\section{LK GAMES}

OKER

t.

ALL GUIDE 19651966

IP HIGH SCHOOL BASKETBALL HARO WAY

ISION

ERBACK 

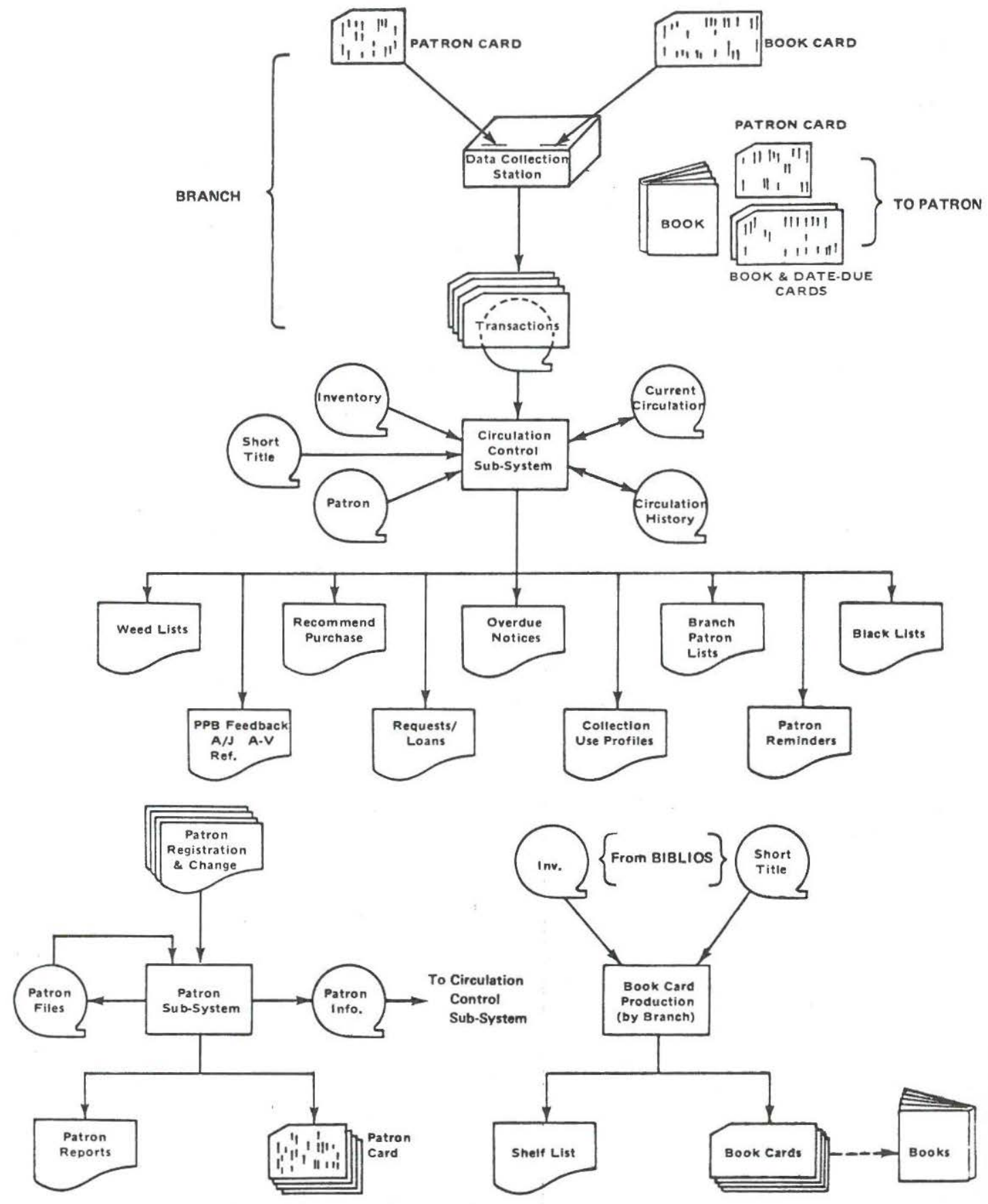

Fig. 10. BIBLIOS circulation control subsystem. 
cards, cassette, or mini-reels). Ideally, the elusive transactor should be able to "read" a label on the book as well as a patron card.

Kimball labels, "Sunburst" tags, magnetically coded swatches and the like have worked and continue to work in the retail trade; there is no reason why they shouldn't work for libraries. The only deterrent seems to be the reticence of their manufacturers to enter an unknown market where, following the Melcher axiom, they are met with a "stubborn, 'show me' attitude when automation is proposed." (8)

The products designed into the circulation control module include: weed lists, patron "black lists," circulation profiles (graphically displaying patron use of each branch's collection), and automatic duplicate ordering. Reports measure circulation from a manager's viewpoint, but not to the exclusion of such bread-and-butter products as overdue notices, registration lists, and related statistical recapitulations.

\section{A WORD ABOUT DOCUMENTATION}

For each program in each subsystem of BIBLIOS, forty unique programs in all, there is a formal package consisting of:

1. A program specification detailing the inputs, processing, outputs, idiosyncracies, and edits of that program;

2. A listing of the COBOL program itself;

3. An operations binder (notebook) section for set-up and run procedures;

4. A user's guide section relating requirements and diagnostics to the librarians using the program including typical problems; and,

5. Assorted total system binders (notebooks).

While some might think "overkill," in automation this is not the case. The BIBLIOS system has yet to fail a scheduled commitment. Further, it is suspected that the mere discipline of documentation caused many serious reconsiderations of program and procedural logic, at the time and on the spot, with the result that BIBLIOS is a reliable system-requiring no major rework and continuing to respond to the library's functional requirements for over two years at this writing.

\section{A WORD ABOUT DEVELOPMENT COSTS}

Both developmental and operational costs for BIBLIOS are known and documented. Specifically, the costs to procure such a system are broken out in Table 1, where each subsystem is examined in terms of the dollars it represents and the assorted tasks required to bring it into being. The totals represent all costs over approximately a three-year period beginning with rough specifications and yielding the first book catalog.

It must be noted that final program specifications and coding were performed for Orange County by a contractor. This approach was chosen, since a good job done on time was wanted. That the approach was valid is 
Table 1. BIBLIOS development costs (including full conversion and publication of first book catalog).

Orange Co. Public Library Analyst

3,360

7,840

2,240

14,560

7,000

35,000

Coordination

1,225

7,679

818

5,310

5,670

20,702

Implementation (K.P., Machine Time, Etc.)

4,772

12,263

4,635

7,879

10,110

39,659

Conversion/Outside

Services

800

53,500

41,370

95,670

Subtotal

10,157

81,282

49,063

27,749

22,780

191,031

TOTAL 
evidenced by the achievement of a successful system on schedule and within budget. This approach reflects a contention that librarians can specify their requirements if they "have a mind to," and that a contracted programming staff can satisfactorily perform to predetermined standards and timeframes if properly directed. In direct contrast to this approach are the incredible schedules developed when requirements are not specified (and frozen), and the suspected monumental costs hidden in lost staff time due to extended parallel operations or simply waiting until "they" get the "... thing" to run right.

The remaining cost components, briefly, reflect direct library analyst time, the cost of coordination meetings, direct key punch and machine time for programs, their test, debug, string test, systems test, and for the bibliographic and book catalog, subsystems conversion and catalog print file generation. The conversion/outside services include a MARC subscription, the creation and use of a group of nine typists to optically scan the library's files to convert them to machine readable form (including error correction), and the contracted services of a photoreproduction house to mechanically compose, print, bind, and deliver 500 sets of the book catalog and 100 sets of the locator guide. These are the costs of setting the system up, staff training, and creating a single operational display: the book catalog.

\section{A WORD ABOUT OPERATING COSTS}

Early in 1965, as a prelude to implementing a book acquisition program, a time/cost study was performed to determine how much it cost the library to order a book (one title). This study detailed and costed the typing, sorting, assignment of vendors, and the reduction of a diversity of paper requisite to creating a purchase order. Excluding the cost of the purchase order form itself, the direct manual cost for this process was $\$ 1.56$ per title, using a clerical rate of $\$ 2.10$ per hour. In the intervening years three things have happened:

First, clerical rates have increased to $\$ 2.79$ per hour which when applied to the unit cost of the 1965 acquisitions study means a direct outlay of $\$ 2.07$ per title (as against the previous $\$ 1.56$ ).

Second, the number of branches has increased which implies that, if the manual system of 1965 could cope with the increased load, it would have required more people and therefore an increase in indirect costs, not to mention the probability of less efficiency due to increased direct costs.

Third, Orange County has automated this function (as well as others). Since Orange County is wont to track costs, it so happens that the cost for creating a purchase order (subpurchase order under the new system) is available. Specifically, Orange County knows computer and peripheral costs and the exact time for processing from actual billings over the past two years. The reduction of these data to a per-unit-handled equivalent, while detailed, is not difficult. Thus, it is possible to deduce the machine costs 
Table 2. Typical processing costs for one title in Orange County Public Library's BIBLIOS system.

\begin{tabular}{|c|c|c|c|c|}
\hline \multirow{2}{*}{$\begin{array}{c}\text { MARC } \\
\text { (Weekly) }\end{array}$} & \multirow[b]{2}{*}{ Bibliographic ${ }^{1}$ Inventory } & \multicolumn{2}{|c|}{ Acquisitions $^{2}$} & Book Catalog \\
\hline & & Order & Receive $^{s}$ & B.C. \\
\hline
\end{tabular}

\section{Run Cost \\ Average Items}

$\$ 325.16$

$\$ 300.40$

$\$ 201.21$

$\$ 1244.94$

$\$ 238.55$

$\$ 238.00$

$\$ 26.00$

Per Period

$\begin{array}{lll}115^{4} & 1,000 & 8,100\end{array}$

$\begin{array}{cc} & \\ \text { Order } & \text { Receive } \\ \$ 1.78 & \$ 0.34 \\ \$ .05 & \text { (Sub P.O.) } \\ .06 \text { (Opscan) }\end{array}$

4000

Cost/Entry

2.83

0.30

0.025

0.028

0.02 (Convelope)

Services

$$
\text { (Opscan) }
$$

$\$ 0.32$

$\$ 0.053$

$\$ 1.89$

$\$ 0.34$

$\begin{array}{ll}0.059 & 0.0006 \\ 0.041 & 0.0028\end{array}$

(Comp/Print) (Comp/Print)

TOTAL

Example:

Cost of entry from initial input to display in book catalog (including Convelope; excluding MARC source: \$2.77).

$140 \%$ Bibliographic.

$260 \%$ Bibliographic.

3 Includes invoice, vendor, and budget displays.

4 If all new entries to system came from MARC. 
equitable to those for the earlier manual effort: creating a purchase order for one title, including the purchase order form, now costs $\$ 1.89$.

Similar economies can readily be documented as can the increases in service to our patrons at no increase in staff. The operating costs for those BIBLIOS subsystems in regular use are given in Table 2. Only two entries on this table are not self-explanatory.

\section{$M A R C$}

MARC, which is indicated as processed weekly, has not been run for over a year. The explanation is simple economics. It costs $\$ 0.32$ to manually place a bibliographic description on file (excluding the time spent to circle an entry in Publishers' Weekly $(P W)$ vs. $\$ 2.96$ to process the same entry from MARC. This cost for MARC includes the subscription cost prorated to selected entries, the translation and format of all MARC entries, the automatic release of those entries of limited value to a public library, the cumulation of entries which may be of value, the extract and transfer of those entries selected, and the reporting via indices and full listings for the contents of the cumulated file. The unit cost is the actual processing cost for MARC II files for one year divided by the number of titles processed through the rest of BIBLIOS during the same period. This cost does not include corrections to selected MARC entries (invariably in the call number and author fields for consistency with the library's existing files). The costs affiliated with processing corrective input closely resemble those for bibliographic, e.g., \$0.32 each.

\section{Prorated Bibliographic Input}

BIBLIOS works on pre-cataloged entries. The 60 percent bibliographic input shown under acquisitions relates to the full initial description for a title being entered by a book selector to effect its order and subsequent reporting; the 40 percent shown under bibliographic is for cataloger input to adjust the entry for title-page accuracy, consistency with existing files, and, for nonfiction, the assignment of call numbers and subject headings. It is important to note that for reorders against a title already in the system, no bibliographic input is required. In the case of reorders, the per title cost is $\$ 0.88$ including subpurchase order forms.

\section{REFERENCES}

1. John C. Kountz, "Cost Comparison of Computer versus Manual Catalog Maintenance," Journal of Library Automation 1:159-77 (Spring 1968).

2. Daniel Melcher, Melcher on Acquisition (Chicago: American Library Association, 1971), p. 135.

3. John C. Kountz and Robert Norton, "BIBLIOS-A Modular Approach to Total Library ADP," Proceedings of ASIS 6:39-50 (1969). 
4. John C. Kountz and Robert E. Norton, "BIBLIOS-A Modular System for Library Automation," Datamation 16-79-83 (Feb. 1970).

5. Orange County Public Library presently has twenty-six branches, three bookmobiles, and plans for at least three more branches and an additional bookmobile in the near future.

6. Kountz and Norton, "BIBLIOS-A Modular Approach."

7. The device affiliated with the book depends on the transactor. The only requirements are that it mechanically represent the key for the book, be practically indestructible, and that it can be prepared mechanically. This last consideration is an absolute when there are 800,000 volumes to convert.

8. Melcher, Melcher on Acquisition, p. 135. 